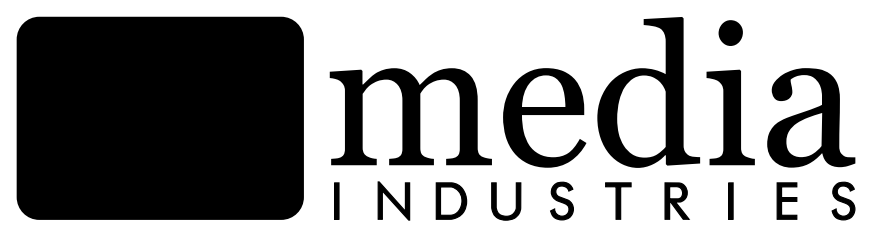

\title{
Media Industries in Revolutionary Times
}

\author{
Marwan M. Kraidy 1 \\ University of Pennsylvania \\ mkraidy [AT] asc.upenn.edu
}

\begin{abstract}
:
This essay explores media industries in revolutionary times. Against the backdrop of the Arab uprisings, with specific references to Egypt, Syria, and Tunisia, I summarize shifts that have occurred in the transnational, pan-Arab media sphere and provide snapshots of national media systems in flux. The Arab uprisings have spawned a wide array of new media, including a variety of new television channels, online media portals, digital video series, comedy programs, talk shows, and religious content. How these institutional and aesthetic developments will be integrated into national and pan-Arab media industries is an important question. In addition, entertainment has become a major issue of contention as Islamists of various stripes have ascended to power in Arab Spring countries and have worked to morally reshape the media industries, encountering vociferous resistance from creative people in arts and media and from counterrevolutionary forces most clearly visible in Egypt, which is reverting to a military dictatorship. Though the current situation is too chaotic to predict future trends, this essay tries to raise questions about new dynamics of production, precarity, and authorship in still-evolving revolutionary contexts.
\end{abstract}

Keywords: Citizenship, Deregulation, Political Economy, Regulation, Television, Middle East

The popular uprisings that have rocked the Arab world since December 2010 have had a transformational impact on Arab media industries. Old pan-Arab television news networks have changed their editorial orientations and new channels have arisen to challenge incumbents. Musical releases have been slower and fewer, and the music video industry has all but screeched to a halt. In Arab countries that experienced uprisings, national media landscapes have been reshaped. Conservative Islamists like the Muslim Brotherhood in Egypt and the Ennahda movement in Tunisia sought to "cleanse" television through new policies after both groups won elections deemed free and fair, while mobs of their radical brethren, the Salafis, stormed television channels airing content that they judged offensive according to their interpretation of Islam. As established players come under assault, new ones flex their muscles, reflecting newly politically ascendant forces. At the same time, the fortunes of various television genres changed, with talk-show ratings skyrocketing in Egypt to the point that they competed 
with Ramadan drama in July and August 2013. Shifting relations between states also affect the media industries, most spectacularly in the Egyptian-Turkish row over the military coup that toppled elected Egyptian president Muhammad Morsi, who was supported by Turkey's prime minister Recep Tayyep Erdoğan. The dispute led to a boycott of Turkish drama by Egyptian and other Arab channels starting in August 2013. Since then, the reassertion of military rule in Egypt has spectacularly shown that as enemies of media independence, secular regimes can be worse than Islamists. Media control and censure in revolutionary times are about raw political power more than they are about religious piety.

The most important change in the television news industry brought about by the Arab uprisings has been the editorial realignment of $\mathrm{Al}$ Jazeera and the ensuing advent of $\mathrm{Al}$ Mayadeen, based in Beirut and led by Al Jazeera's erstwhile bureau chief in the Lebanese capital: the Tunisian journalist Ghassan Bin Jeddu. Throughout the fall of 2011 and spring of 2012, as the Syrian uprising moved into a brutal civil war that increasingly dominated news coverage, Al Jazeera emerged as the chief media cheerleader of the rebels taking arms against Bashar al-Assad. This caused fundamental disagreement within the channel, with several employees resigning from the Beirut bureau, which was in charge of Syria coverage, in protest against "directives from above." I was on research leave in Beirut at the time and did several interviews for Al Jazeera English's program The Listening Post, which covers media issues. There, in Al Jazeera's offices in Quntari at the edge of the Hamra district, tension was manifest among the employees. An initial trickle of departures gained momentum as stories emerged of Al Jazeera showing contrived footage of Syrian regime atrocities, and as the contrast between the Qatari channel's histrionic coverage of Syria and its minimal reporting on the popular uprising in Bahrain became flagrant.

Since its launch in 1996, Al Jazeera has been famous for its relentless criticism of the Saudi royal family and its policies. Its talk shows have hosted Saudi dissidents; its newscasts have focused on Saudi domestic problems; and its reports have highlighted negative aspects of Saudi foreign policy. The emir of Qatar launched Al Jazeera after executing a coup against his father, a protégé of the Saudis. The Saudis from the outset led a commercial boycott of the Qatari channel, and in 2003 they launched the Dubai-based Al Arabiya to counter Al Jazeera's onslaught on Saudi interests. In addition to the Saudis not tolerating dissent among the members of the Gulf Cooperation Council (GCC, a club of the region's oil monarchies), some of the seeds of discord came from Qatari support of the Muslim Brotherhood, which the Saudis perceived as a threat to the Wahhabi, or Salafi, doctrine at the heart of the Saudi clerico-political system. The Saudi-Qatari feud animated many a talk show, and Arab analysts and columnists followed its every step.

The Arab Spring upended these political-media dynamics. After an initial period of shock as Tunisia's Ben Ali, Egypt's Mubarak, and Yemen's Saleh-all allies of the Saudis-were unseated, the Gulf monarchies undertook nothing short of a counterrevolution. Qatar emerged as the patron of the Muslim Brotherhood in Egypt and the Brotherhood-affiliated Ennahda in Tunisia, both winners of post-dictatorship elections, while the Saudis sponsored emerging Salafi parties, especially the al-Nour in Egypt. The Saudis fought a losing battle to keep Saleh in power in Yemen, which they consider their backyard. But the Bahraini upheaval, which raised the specter of regime change within the GCC, compelled the Gulf rivals-Qatar and Saudi Arabia - to pull together, though a rift over who is the leading sponsor of the Syrian rebels remains. Under the Peninsula Shield defense clause of the GCC, Saudi armed forces entered Bahrain through the ten-mile causeway (bridge) linking the two kingdoms over Persian Gulf 
waters to succor the Bahraini monarchy in repressing the rebellion. The Sunni Gulf monarchies have long accused Shiite Iran of meddling in their affairs through Bahrain, which has a Shiite majority. Saudi Arabia and Kuwait also have significant Shiite minorities, and in the former, Shiites predominate the oil- and mineral-rich Eastern Province. In an unfortunate sign of the times, sectarian incitement and mobilization have become both unabashed and systematic, though it is important to recall that the rising intensity and frequency of sectarian agitation stems mainly from geopolitical instrumentalization and much less from fundamental doctrinal disagreements.

As this happened, erstwhile archrivals Al Jazeera and Al Arabiya enacted a stunning editorial convergence-confronting Al Mayadeen, a new channel with a limited following and a smaller audience; Hizbullah's Al Manar; Iran's minor player Al-Alam; and Syrian channels - over the Syrian revolution in what can be characterized as a new Middle Eastern War of the Airwaves. Shifting geopolitical agendas thus shaped a major reshuffling of the pan-Arab television news industry.

At the same time, a renaissance of national broadcasting, terrestrial and satellite, was underway. Egypt is the best illustration of this trend. As Mubarak fell in February 2011 and political life heated up leading to legislative elections, talk-show ratings skyrocketed, driven by newly found freedoms to debate politics in a no-holds-barred fashion. Unexpected ratings boosters happened, such as the resignation of Egypt's first post-Mubarak prime minister on a live television talk show. In moments of upheaval when people are thirsty for information about local politics and security, it is not surprising that local and national news, current affairs, and talk shows take primacy over entertainment fare, which in the Arab world tends to be produced by transnational satellite channels with weak local connections and coverage.

The Arab Spring brought a mixed bag for entertainment. On the one hand, newly enfranchised Islamist parties in Egypt and Tunisia sought to cleanse entertainment of sexual content to bring it in line with their vision of the virtuous society. The security situation in Syria drove Syrian drama production to Beirut, Cairo, and Abu Dhabi. Even in Cairo, deteriorating security conditions delayed or undermined production schedules. Pop stars like Amr Diab and Shereen Abdulwahhab were forced to delay album releases traditionally timed for Eid al-Fitr, the major Muslim holiday that concludes the holy month of Ramadan. In Egypt, Syria, and Tunisia, actors, singers, and other celebrities were dragged into wars of words and ended up on various groups' online walls of fame and walls of shame. Many were threatened, others were kidnapped, some were killed.

The June 30, 2013, military coup in Egypt that unseated elected-president and Muslim Brotherhood figure Muhammad Morsi approximately a year into his tenure reshuffled the media industry chessboard again. Pro-Mubarak celebrities who had been on the defensive during Morsi's rule were newly visible, leading the charge in a vicious media campaign against the Muslim Brotherhood, now labeled terrorists. Many observers were surprised to see that Egyptian and other drama series during Ramadan 2013-Ramadan is the high season of television drama in the Arab world ${ }^{2}$-demonized clerics more than cops and featured the boldest-yet themes and scenes featuring sexuality, addiction, drugs, rape, the marriage of minors, and radicalism. The usual critics aired customary objections, but reactions to increasingly bold treatment of burning social issues by television drama were strangely muffled, as if rendered less problematic by the rough-and-tumble of life in revolutionary times. 
The military coup in Egypt also upended Egypt-Turkey relations. Turkey's prime minister, Recep Tayyip Erdoğan, was a strong supporter of Egypt's president, Mohammed Morsi. Erdoğan's party, the Justice and Development Party (Turkish acronym: AKP) and the Muslim Brotherhood are ideological kindred spirits. The Turkish leader was highly critical of the coup that deposed Morsi, and a war of words ensued between Turkish and Egyptian leaders in August 2013, as Ramadan was concluding. As a result, the Egyptian creative class, which chafed under Brotherhood rule and is notoriously prickly when it comes to foreign criticism of Egypt, began promoting the idea of boycotting Turkish television drama, which in the last half decade has competed head-on with Egyptian and Syrian drama for prime-time air time. ${ }^{3}$ Erdoğan, never known for his rhetorical caution, attacked Al-Azhar, Egypt's venerable religious university, for supporting the coup, saying that history would judge Al-Azhar harshly. Immediately, private Egyptian channels began canceling deals with Turkish production firms, Egyptian op-eds grew more hostile toward Turkey, and several Egyptian celebrities opined that "boycotting Turkish drama is a patriotic duty." In short order, Egyptian-Turkish artistic collaborations were halted, Turkey reconsidered billions in aid it had pledged to Egypt, and the boycott began taking shape. Gulf channels, most visibly Dubai TV and Abu Dhabi TV, announced they were joining the boycott in solidarity with Egypt's media companies, though their real reasons may have been political, since the United Arab Emirates treats the Muslim Brotherhood like a criminal cult and was one of the main backers of the June 30, 2013, military coup that toppled Morsi. In contrast, behind Egyptian media's political posturing lies anxiety about fierce commercial competition of Turkish drama, a boycott of which would create, some believe, breathing room for Egyptian productions (dozens of Egyptian drama series were produced but not broadcast during the last three years, owing to the political situation but also to competition from Syrian and Turkish productions).

Finally, the Arab uprisings spawned a vibrant scene of dissident media and culture. Revolutionary graffiti, dance, theater, puppetry, murals, hip-hop, and poetry exploded from Morocco to Iraq and within months moved from the street to the screen and to art galleries. Remarkable among these is the flourishing of video in all its forms. In Bahrain, Syria, and Tunisia, mobile-phone videos bore witness to atrocities, propagandized for various parties, mocked dictators, and showcased a variety of animation, dance, theater, and song. The rise of more slickly produced satirical videos by groups like Kharabeesh and Masasit Mati is a notable phenomenon because such productions have the potential to find a place in mainstream media industries, infusing them with new, young talent and with the edge of revolutionary aesthetic. Take Masasit Mati's Top Goon-Diary of a Little Dictator, (2011) a satirical finger-puppetry video series on the web that broke through mainstream consciousness in global media coverage. Using a handful of finger puppets to ridicule Assad and the brutality of his regime, the group produced its first season with personal effort, donated labor, and limited personal savings. After Masasit Mati's attempt to crowdfund the second season via a Kickstarter campaign failed, the group's visibility attracted funding from European foundations like the Netherlands' Prince Claus Fund. They now have a slick website, and though there may not be a third season, members of the group are now leveraging their fame for new creative ventures. Because of its low costs and low barriers to entry in the age of YouTube, video has arisen as a key revolutionary medium and a primary path to mainstreaming dissident cultural production.

What do these developments mean for media industries at large? First, they demonstrate that in some parts of the world, media industries are entangled in a political-economic-cultural nexus that is ever shifting and the consequences of which are often unintended. Notably, seemingly 
unending reserves of petrodollars have enabled the Gulf monarchies to exert enormous influence over the politics and media of revolutionary countries like Egypt, Tunisia, and Syria. Policy differences between Qatar and Saudi Arabia will continue to be a major shaper of transnational and national media industries throughout the Arab world: who would have thought that archrivals Al Jazeera and Al Arabiya would editorially converge to that point?4 Second, new patterns of creative migration emerge within a region that shares a language and a transnational media industry when various countries experience various levels of violence, insecurity, and persecution of creative workers. Research will need to examine the ultimate impact of the exodus of Syrian directors and producers throughout the Arab world. Already, this is helping reestablish Beirut as a global art and cultural-production city. Third, the work of creative resistance, often created and disseminated under extremely difficult security conditions, gives a new meaning to the notion of precarity in creative labor, broadening its prevailing understanding as economic contingency to include torture-risking and death-defying creative work. Often the work of anonymous collectives, such works will also challenge prevailing notions of authorship and remuneration as they make inroads in the mainstream media industries.

1 Marwan M. Kraidy is the Anthony Shadid Chair in Global Media, Politics and Culture and Director of the Project for Advanced Research in Global Communication (PARGC) at the University of Pennsylvania's Annenberg School for Communication. His last book, Reality Television and Arab Politics (Cambridge University Press, 2010), won three prizes. He is currently working on Creative Insurgency: Arab Dissent in an Age of Revolution.

2 Marwan M. Kraidy and Joe F. Khalil, Arab Television Industries (London: BFI/Palgrave Macmillan, 2009), particularly chapter 5.

3 Marwan M. Kraidy and Omar Alghazzi, “Neo-Ottoman Cool: Turkish Popular Culture in the Arab Public Sphere," Popular Communication 11, no. 1 (2013): 17-29.

4 For a long time, there have been signs of divergent agendas between the two sponsoring countries, and in August 2013 the Saudi-Qatari feud appeared to have returned in full force after the Wall Street Journal published statements it attributed to royal prince and head of Saudi intelligence Bandar Bin Sultan, who allegedly said, "Qatar is only 300 people and a TV channel . . that is not a country," setting the Qatari Twittersphere ablaze with patriotism and condemnation. See Adam Entous, Nour Malas, and Margaret Coker, "A Veteran Saudi Power Player Works to Build Support to Topple Assad," Wall Street Journal, August 25, 2013.

\section{Bibliography}

Entous, Adam, Nour Malas, and Margaret Coker. “A Veteran Saudi Power Player Works to Build Support to Topple Assad." Wall Street Journal, August 25, 2013.

Kraidy, Marwan M., and Joe F. Khalil. Arab Television Industries. London: BFI/Palgrave Macmillan, 2009.

Kraidy, Marwan M., and Omar Alghazzi. “Neo-Ottoman Cool: Turkish Popular Culture in the Arab Public Sphere." Popular Communication 11, no. 1 (2013): 17-29. 


\section{(cc) EY-NC-ND}

Copyright ( ) 2014 (Marwan Kraidy). Media Industries is an open-access, peer-reviewed, online academic journal. As such, we aim to participate in the open exchange of information. This work is licensed under a Creative Commons Attribution Noncommercial No Derivatives (by-nc-nd) License. Under this license, this work is available for sharing and noncommercial distribution provided the appropriate attribution is given. 